\title{
Covid-19 Pandemic: Vulnerability to the Households Financial
}

\author{
$1^{\text {st Nugroho Tulus Rahayu }}$ \\ Doctorate of Management Programme \\ Diponegoro University \\ Semarang, Indonesia \\ tulushantoro@gmail.com
}

\author{
$2^{\text {nd }}$ Harjum Muharam \\ Doctorate of Management Programme \\ Diponegoro University \\ Semarang, Indonesi
}

\begin{abstract}
The Covid-19 pandemic has an impact on almost all sectors of the economy and community activities. This study aims to determine the impact of Covid-19 on the household economy and the effectiveness of social protection by the government. The method in this research is literature study. The literature sources in this study comes from primary and secondary sources. Primary sources are in the form of interviews and research reports, while secondary sources used are in the form of writings on other researcher, and similar writings on matters that the author has not directly witnessed or experienced. The results of this study state that the Covid-19 pandemic has a significant impact on the households economy, this is due to restrictions on economic activity carried out by the government. Termination of Employment that occurred during the pandemic had an impact on the weakening of the households economy. The declining of theor financial makes them unable to meet the daily needs. Based on the problems, the government requires to provide social assistance to the affected communities. However, in several case the social assistance is deemed ineffective and not on target.
\end{abstract}

\section{Keywords-Covid-19, Financial, Households}

\section{INTRODUCTION}

The COVID-19 outbreak was first identified in Wuhan, China in December 2019. as of August 2020, there were 23 million confirmed cases with 800,000 deaths worldwide [1]. This pandemic has become one of the most destructive forces that have experienced mankind in the last 100 years [2]. The Covid-19 outbreak which first entered Indonesia in early March 2020, has had a major impact on people's lives, especially in the economic sector. One of the impacts of the outbreak is the slowdown in economic growth in Indonesia, which was recorded at only 2.97 percent in the first quarter of 2020. Even though at that time, the Covid19 outbreak had just hit in March. It is estimated that in the second quarter the decline in economic growth will be more pronounced given the widespread impact of the pandemic. Changes in the economic sector caused by Covid-19 have had a broad impact on economic sectors. Several sectors have experienced a decline and several sectors are still running despite the pandemic. These changes can be seen in the table as follows:

Based on table 1, it can be seen that economic growth in the first quarter of 2020 (Q1-2020) against the fourth quarter of 2019 (QIV-2019) experienced a decline in several sectors. The sector that experienced the largest decline was the education services sector by 10.39 percent. Other sectors such as the government administration sector and the construction sector also experienced a significant decline in which respectively experienced a decline of 8.54 percent and 6.92 percent. Year on years economic growth in QI-2020, almost all sectors experienced a growth slowdown compared to the previous year. Starting from the sector that has the largest contribution to GDP, namely the manufacturing sector which grew 2.06 percent, slower than the same period in the previous year which experienced growth of 3.86 percent.

The sector with the second-largest contribution, namely the trade sector, also experienced slowing growth. In QI2020 , the Trade sector experienced growth of only 1.60 percent, experiencing a slowdown in growth compared to last year's growth in the same period of 5.26 percent. Followed by sectors that have the third largest contributor to GDP, namely the agriculture, forestry, and fisheries sectors. This sector also experienced a growth slowdown from the previous year. In QI-2020, the Agriculture, forestry, and fisheries sectors experienced growth of 0.02 percent, experiencing a slowdown when compared to the previous year which experienced growth of 1.81 percent.

Based on the aforementioned weakening of the sectors, some sectors have persisted and even have increased. These sectors include the financial services and insurance sector, health services and social activities, information and communication, and education services. The Financial Services and Insurance sector experienced the highest growth of 10.67 percent, higher than the previous year's growth of 7.33 percent. In the second position, the sectors that experienced an increase in growth were the Health Services and Social Activities sector by 10.39 percent, higher than the growth in the previous year of 8.61 percent. The sector that experienced further growth was the information and communication sector by 9.81 percent, higher than the growth for the previous year of 9.03 percent. Finally, the education services sector grew by 5.89 percent, higher than the growth in the previous year of 5.62 percent.

QI-2020 GDP growth only grew by 2.97 percent, smaller than the previous year which grew by 5.07 percent in the same period. This is because sectors that have a high contribution to GDP, such as the processed industry sector, the trade sector, and the agricultural sector, experience weakening growth, which has an impact on the contribution of GDP growth. Another sector that has been badly affected is tourism. The decline in the number of foreign tourists and tourists has hit this sector. Hotels, restaurants, tourist attractions, tourism support services 
experienced a significant decline in turnover due to the absence of tourists.

The weakening of some of the sectors previously described was caused by the implementation of government policies to reduce community activities which resulted in an economic slowdown. On the other hand, the spread of the Covid-19 outbreak has caused a number of business activities to stop, leading to the Termination of Employment (PHK) which has an impact on increasing unemployment. The impact of the spread of this epidemic is increasingly felt when the government is faced with the situation and economic conditions of the people which are getting weaker due to their loss of jobs. As a result, their daily needs become constrained due to loss of income. The impact of this widespread outbreak has been felt in almost all regions in Indonesia.

Based on a survey conducted by LIPI in August 2020 on 1,548 respondents in 32 provinces. It is known that more than $50 \%$ of families experienced financial difficulties as a result of the Pandemic. So that it is hoped that assistance from the government can be given to the affected communities. Meanwhile, during the pandemic the financial difficulties experienced occurred due to the inability to supply foodstuffs; pay routine monthly deeds such as electricity, water, school education; then routine installment payments such as credit cards, KPR, motorized vehicles; as well as difficulties in meeting non-food needs such as clothing and secondary needs. Still from the results of the same survey, it is known that the most affected families are families with income below 1.5 million per month; and families with incomes below 5 million per month as a whole. This means that the lower the monthly households income, the more financial difficulties will be.

Some of the factors that caused financial difficulties for low-income families during the pandemic, among others, were job losses or decreased income due to the impact of the pandemic, reduced working time, then many lost their main jobs because of the sector they worked in was affected by the pandemic. Then also reduced business turnover. Some of these factors are the impact of a decrease or loss of income due to the pandemic.

Then the second is the lack of savings. As is known, the people in the lower middle group have relatively no savings for reserve funds. The impact is there is no back up when they lose their main source of income. And the third is the absence of a job or a source of side income.

This study intends to examine the impact of the Covid19 pandemic on households economic resilience, especially for certain income groups. What causes resilience between families to bias varies. Is it only economic factors or are there other factors that contribute to the economic resilience of the households. Besides, this study also intends to examine the impact and effectiveness of government assistance in providing a social safety net.

The another studies commonly finds an effect of pandemic towards macro economic. In various countries, the economic sectors that have felt a significant impact from the Covid-19 pandemic are sectors that pay low wages and employ minority groups [3]. Yang Yang, Hongbo Liu, and Xiang Chen [4] states Covid-19 has an impact on decreasing demand from the restaurant. Charl de Villiers [5] states that social restriction is needed to control the pandemic and make economics keep working. One of the policies implemented by the government in shaping social resilience in South Asia is the Covid Emergency
Fund (CEF), the fund is used to strengthen and help the economy of people in the Indian region [6]. Then in Jamaica in balancing the lives and livelihoods of its people, the Jamaican government issued a stimulus package of $\$ 25$ billion, the economic stimulus was used to manage the impact of the pandemic on the workforce, boost the economy, support income, and business and protect workers [7]. However, this study focus on the impact of the pandemic towards micro scale economic actors especiall in Indonesian case. Therefore, this crisis also has a significant effect for several groups of community. Especially low-middle income households. Therefore, this research also try to find an aswer from governmrnt policy towards economic impact.

\section{METHOD}

In this study, the literature study method was used. The literature method is one of the data collection methods used in social research methodologies to trace historical data. Meanwhile, Sugiyono[8] states that Literature is a record of past events in the form of writings, pictures, or monumental works of a person. Thus, library research is a series of activities relating to methods of collecting library data, reading and taking notes, and processing research materials.

Judging from the closeness of the content, literature can be classified into two. First, the primary source (primary source), and the second secondary source. Primary sources are original essays written by someone who saw, experienced, or worked on their own. This kind of literature material can be in the form of diaries (autobiography), theses, dissertations, research reports, and interview results. Besides, the primary source can be in the form of reports on the eyes of a match, population census statistics, and so on.

Meanwhile, what is meant by a secondary source (secondary source) is writing about other people's research, reviews, summaries, criticisms, and similar writings on matters that the author has not directly witnessed or experienced. Secondary literature materials are found in encyclopedias, dictionaries, handbooks, abstracts, indexes, and textbooks.

In carrying out literature research activities, primary literature sources should be used with more authentic information. However, primary literature material relevant to the researcher's problem is not always available, or because of the limited time, it is difficult to obtain. When this happens the researcher is forced to use secondary literature material. It is necessary to consider the author's 'bias' because this information does not come from direct sources.

\section{RESULTS AND DISCUSSION}

The Covid-19 pandemic that has occurred in Indonesia since March 2020 has had a significant impact on various social and economic activities. The social restrictions imposed by the government have greatly reduced demand and income from various sectors of the economy. The decline in demand and income from various sectors of the economy has also caused many companies to lay off their employees. Based on a statement from the Indonesian Chamber of Commerce and Industry (Kadin) delivered to DDTCNews, it was stated that there were 6.4 million workers who were laid off or experienced layoffs due to the Covid-19 pandemic, the layoffs carried out are the effect of reduced turnover in various economic sectors. 
In various countries, the economic sectors that have felt a significant impact from the Covid-19 pandemic are sectors that pay low wages and employ minority groups[3]. According to Yang Yang, Hongbo Liu, and Xiang Chen, Covid-19 has an impact on decreasing demand from the restaurant sector due to decreased income from the household financial. All sectors cannot operate and many sectors have also permanently closed their businesses, while sectors that continue to operate must carry out social restrictions following applicable health protocols [5]. One of the policies implemented by the government in shaping social resilience in South Asia is the Covid Emergency Fund (CEF), the fund is used to strengthen and help the economy of people in the Indian region [6]. Then in Jamaica in balancing the lives and livelihoods of its people, the Jamaican government issued a stimulus package of $\$ 25$ billion, the economic stimulus was used to manage the impact of the pandemic on the workforce, boost the economy, support income, and business and protect workers [7]. In Singapore, there are several key fiscal, analytical, operational, and political capacities, most of which were built after the 2003 SARS crisis, which enabled the Singapore state to provide a strong initial response to the COVID-19 outbreak. This is evidenced by the low rate of COVID-related deaths in Singapore and minimal community transmission within the resident community and its permanent residents [9]. During the Covid-19 pandemic, the International Labor Organization (ILO) also encourages and provides convenience for workers in terms of simplified administrative transitions, reduced costs for entrepreneurship training, financial literacy, and access to various financial services.

The Indonesian Central Statistics Agency (BPS) in August 2020 recorded an increase in the percentage of the Open Unemployment Rate (TPT) of 7.07 percent, an increase of 1.84 percent compared to August 2019. The increase in unemployment and layoffs has had a significant impact on the households financial. workers who lose their jobs cause their incomes to drop so drastically that they are unable to meet their basic needs. IPB Households Economic Experts stated that as many as 55.5 percent of families in Indonesia experienced a decline in income during the pandemic. According to a survey conducted by LIPI, families with an income of Rp 1.5 million per month were greatly affected by the Covid-19 pandemic, on average families with an income of 1.5 million did not have savings or reserve funds that could be used to help overcome economic difficulties. in times of pandemic. Based on the statement of Bhima Yudisthira as an INDEF economist, middle-class families are also affected by this pandemic, this is because middle-income families can only survive on their savings, while social assistance provided by the government cannot be absorbed by them.

From an individual perspective, the layoffs that occur cause them to postpone their needs and wants. The delay in fulfilling these needs occurs due to a lack of funds to meet the necessities of life. This condition can get worse if the individual has a households that they must meet their needs. The needs that need to be met by households include the need for education funds and other unexpected needs. The households's need for education funds alone can put psychological pressure on all households members to be met immediately. This condition can be an opportunity to create uncertain life situations such as increasing households debt. This increase in debt can make the households economy tougher if it is not supported by the income they get. In dealing with situations like this, household economic actors experience anxiety because, without the support of income, the necessities of life to implement health protocols will also be disrupted. The need for consumption of nutritious food to increase the body's immunity in the face of a pandemic will be disrupted and make families without income vulnerable to contracting covid-19. Self-employed workers who lose their income are also likely to go bankrupt.

The households is the smallest unit but largely determines the course of the economy in a country. The households also the first line of defense against the Covid19 virus, the impact that is felt most by families is a decrease in income and cannot be separated from the large number of people who have lost their jobs. As a result of the pandemic, the households economy has decreased, causing them to save their purchasing power, and this has created a multiplier effect on various sectors of the economy. Families whose economies are heavily affected by covid-19 will make savings on non-food consumption, and this will have an impact on non-food economic sectors. The economic difficulties that have occurred due to the pandemic have made it difficult for families to meet their various needs for clothing, food, and shelter. Sandiaga Uno stated that the government needs to pay attention to the households economy because if the downturn in the households economy does not immediately rise, it will cause a food crisis and a social crisis.

Various kinds of strategies and efforts must be made by the households to survive in an uncertain situation like today. Families who are greatly affected by this pandemic must change their behavior, habits, and mindset so that the income they have can help support their lives. The habit they change is the fulfillment of food consumption, the households must be more economical and choose food consumption according to their economic conditions. Meanwhile, families who live in big cities and lose their jobs, but do not yet own a house or just rent a house, must try to find other income to be able to meet their rental needs. Families with incomes below 1.5 million have to change their habits even more, such as reducing their frequency of eating. Apart from these economic problems, social problems in the household also have a negative impact. The much-increased allocation of time at home can create problems if not managed properly.

The government has a role in helping to improve the households economy, one of the things that the government has done is to provide social assistance to affected communities. There are several social assistance provided by the government including basic needs assistance, cash assistance, village fund BLT, free electricity, pre-employment cards, employee salary subsidies for salaries below 5 million, and BLT for micro and small businesses. Among the several social assistance provided by the government, there are still many that are considered ineffective in helping improve the economy of the affected families. Social assistance is deemed ineffective because there are still a lot of inadequately targeted assistance.

Mufida [10] states that there are various polemics of social assistance provided by the government. The polemic that occurred included the confusing distribution 
of social assistance because there were a lot of invalid data so that the distribution of social assistance was uneven. There are several social assistance and criteria for different social assistance recipients for the community, but the data on families affected by Covid-19 are out of sync so that there is often the distribution of overlapping social assistance for 1 households while other families do not receive assistance, even though the households fit into the criteria for beneficiaries.

Besides, pre-employment cards that are used as a social safety net to help the households's economy are also considered ineffective, because what the affected families need is direct and concrete assistance. Pre-employment cards that are used as assistance for someone to find work are not suitable if they are given during a pandemic, because employment tends to decline and many companies lay off their employees.

The effectiveness of providing social assistance is highly questioned by several economic experts in Indonesia. Chatib Basri once said that the social assistance provided by the government has not been effective and needs to be increased, the consumption of the community and household which has decreased requires more special attention. Based on Chatib Basri's statement, the government needs to provide cash assistance to the poor so that they can spend this money and be able to help encourage public consumption. For families with stable economies, the government needs to provide concessions or support so that they can spend their money.

Based on Mufida [10], the social assistance provided by the government is less effective because some government officials at the RT / RW, sub-district, or village level take advantage of the distribution of social assistance to get benefits, such as asking for a little reward or even the social assistance provided is not to those who need it more. Many of the social assistance provided did not reach families affected by Covid due to lack of data and some groups did not distribute the assistance to entitled people, but they gave it to families related to that group. Citizens or families living in villages tend to get less attention and there are still many who have not felt the effects of the social assistance that has been provided. Supervision from the government and related institutions is needed to help distribute and increase the effectiveness of the social assistance provided.

In addition to the many polemic occurrences, the social assistance provided by the government has not been able to restore the households's economic condition to normal, because the assistance is not always provided, the role of household members is also very much needed to help restore the households economy. Intelligence in managing the resources owned is an inseparable part. With the ingenuity possessed in managing resources, it will be able to increase the chances of being able to survive during an uncertain pandemic situation. One of the resources in the households is finance, this plays a very important role in improving welfare in the households. In the current pandemic, families can manage finances by cutting unnecessary expenses and prioritizing important needs first..

\section{CONCLUSION}

The Covid-19 pandemic that has occurred in Indonesia since March 2020 has had various significant impacts and changes in various economic sectors, lifestyles, and people's habits. Social restrictions imposed by the central government have resulted in reduced demand and income from various sectors of the economy. The impact of the Covid-19 pandemic is very much felt by the households economy as the smallest sector in the economy. Termination of employment (PHK) and an increase in the unemployment rate affect the households economy, namely a decrease in the income of the households economy so that it is difficult for them to meet their basic needs. Families with an economy of 1.5 million are particularly affected by current conditions, as those with an income of 1.5 million tend not to have bailouts to help them support their economy. There are several social assistance provided by the government including basic needs assistance, cash assistance, village fund BLT, free electricity, pre-employment cards, employee salary subsidies for salaries below 5 million, and BLT for micro and small businesses. Social assistance from the government is needed to help boost the households economy, but social assistance provided by the government tends to be less effective. Several surveys stated that the assistance provided by the government was not well-targeted and many groups took advantage of the distribution of social assistance.

\section{ACKNOWLEDGMENT}

We thank our colleagues from Doctorate Program of Diponegoro University who become of the author affiliation.

\section{REFERENCES}

[1] Nadim, M. K., et al. (2020). COVID-19-associated acute kidney injury: consensus report of the 25th Acute Disease Quality Initiative (ADQI) Workgroup. Nature Reviews Nephrology, 1-18.

[2] DeBerry-Spence, B., \& Torres, L. T. (2020). "Don't give us death like this!" Commemorating Death in the Age of COVID-19. NBER Macroeconomics Annual. DOI: https://doi.org/10.1086/711832

[3] Wilson, D. P. (2020). Covid-19 and the Low Paid: Early Analysis of Labour Force Survey. ies Briefing.

[4] Yang Yang, H. L. (2020). COVID-19 and restaurant demand: early effects of the pandemic and stay-at-home orders. Emerald.

[5] Charl de Villiers, D. C. (2020). The South African government's response to COVID-19. Journal of Public Budgeting, Accounting \& Financial Management.

[6] Upadhaya, B., Wijethilake, C., Adhikari, P., Jayasinghe, K., \& Arun, T. (2020). COVID-19 policy responses: reflections on governmental financial resilience in South Asia. Journal of Public Budgeting, Accounting \& Financial Management.

[7] Ricketts, H. (2020), "The Government of Jamaica (GoJ) COVID19 pandemic stimulus response: an opportunity to regulate and formalize?". International Journal of Sociology and Social Policy. Doi: https://doi.org/10.1108/IJSSP-07-2020-0363

[8] Sugiyono. (2014). Metode Penelitian Kuantitaif, Kualitatif dan R\&D. Bandung: Alfabeta

[9] Woo, J. J. (2020). Policy capacity and Singapore's response to the COVID-19 pandemic. Policy and Society, 39(3), 345-362

[10] Mufida, A. (2020). Polemik Pemberian Bantuan Sosial Di Tengah Pandemic Covid 19. 'ADALAH: Buletin Hukum \& Keadilan, 4(1). 